\title{
THE PATRIARCHS \\ OF THE CHURCH OF THE EAST FROM THE FIFTEENTH TO EIGHTEENTH CENTURIES ${ }^{1}$
}

\author{
HELEEN H.L. MurRE-VAN DEN BERG \\ DEPARTMENT OF NEAR EASTERN STUDIES (TCNO) \\ UNIVERSITY OF LEIDEN \\ THE NETHERLANDS
}

\section{INTRODUCTION}

[1] Whoever starts working on the history of the Church of the East in the fifteenth to early nineteenth century encounters considerable difficulties in gaining insight into the developments of the various patriarchal lines. Around 1700, three different patriarchal lines existed alongside each other. One of these was officially recognized by Rome, whereas the two others had some loose connection to the See of Peter but had not obtained official recognition. In the present contribution, I make an attempt to give a critical evaluation of the various lists that are available to modern scholars. In addition, I have amended these lists at a few points. The lists that were composed by Tisserant (1931: 261-3), Fiey (1993: 21-41),

1 The research for this article was made possible by a subvention from the Netherlands Organization for Scientific Research (NWO). However, this article would not have appeared in the present form if the editor of Hugoye, Dr. George Kiraz, had not encouraged me to publish this list that was originally intended as a mere appendix to another work, and if my husband Jan Murre had not helped in making full use of the new possibilities of internet publishing. 
Tfinkdji (1914), and Lampart (1966: 63-4) have formed the basis of the present list. ${ }^{2}$ Apart from these lists of patriarchs, the main sources for reconstructing the patriarchal succession are the references to patriarchs, natar kursis (designated successors), and bishops in manuscript colophons, as well as a few Syriac historical writings, archival material concerning relationships between Rome and the Church of the East, and, rather important, Vostés edition of the burial inscriptions from the monastery of Rabban Hormizd near Alqosh (Vosté 1930a). In this monastery, the patriarchs of the Church of the East had their see from around 1437 to 1804. ${ }^{3}$ A recent Oxford dissertation, David Wilmshurst's "The Ecclesiastical Organization of the Church of the East, 1318-1913," supplied some important additions, based as it is on a large number of manuscript colophons from the period under discussion. ${ }^{4}$

It should be noted that within the Assyrian Church of the East other lists of patriarchal succession circulate, which, at least for the period under discussion, differ in many points from the list as presented in this contribution. For a discussion of these lists, see J.F. Coakley's forthcoming article, "The patriarchal list of the Church of the East." In his article, a traditional list and a slightly different version of it are compared and evaluated in light of their possible sources. Coakley's article also refers to a third traditional list, which, like the two earlier ones, was composed in the first half

2 Unfortunately, the important work of Samuel Giamil, Genuinae Relationes inter Sedem Apostolicam et Assyriorum Orientalium seu Chaldaeorum Ecclesiam nunc majori ex parte primum editae bistoricisque adnotationibus illustratae (Rome 1902) was not at my disposal. Many of the later lists base themselves on this work. Although this means that most of Giamil's data probably are incorporated in the present work through his successors, I was not able to check them myself. Note further that Giamil's work again is not a primary source, but a compilation of earlier sources, most of which are not readily accessible either.

${ }^{3}$ References to published lists of patriarchs are by name of author. References to manuscripts in published catalogues are by catalogue (for abbreviations, see bibliography) and catalogue number, to which the place and date of copying are added between brackets. A list of the catalogues referred to in this contribution is part of the bibliography.

${ }^{4}$ I thank Dr. David Wilmshurst for his readiness to let me use his unpublished dissertation. His work yielded important information both regarding the history of patriarchal succession and the geography of the area. 
of this century. This list is found in an unpublished manuscript called, History of the Patriarchs of the Aboona Family, by bishop Eliya of Alqosh (1863-1956). This manuscript is in the possession of Mr. Sargoon Aboona. Coakley's work on the latter list is not published. So far, his research suggests that in general these lists are not based on independent historical sources and that in case they differ from the list in the present article, their data usually are less likely to be correct, especially since its composers tried, in different ways, to combine the two "Assyrian" patriarchal lines, that of the Abuna family (the Rabban Hormizd patriarchate) and of the successors of Sulaqa (the patriarchate of Mar Yaqub Khbhisha, Khosrowa, and Qodshanis), into one smooth succession. In a few instances, however, when no sound historical data support either of the lists, the dates or names in the traditional lists may be as good a guess as any other. In those cases I will make a reference to these lists. ${ }^{5}$

Before turning to the lists, a concise presentation of the history of these patriarchal lines is appropriate. After the Mongol devastation of the fourteenth century, we find the patriarchate of the East in the monastery of Rabban Hormizd, near Alqosh in northern Iraq. We do not know much about this patriarchate, only that in 1497, Shimun IV Basidi was the first to be buried in Rabban Hormizd and that he presumably started the hereditary succession in his family, which later was to become known as the Bar Mama or Abuna family. In the middle of the sixteenth century, opposition to the patriarchate of Rabban Hormizd resulted in the counterpatriarchate of Yukhannan Sulaqa, who acquired papal recognition in 1553. Up till Shimun IX (1579-1600), this line was officially in union with Rome, but Shimun IX's successors were less successful in acquiring this recognition. Around 1700, this line seems to have disconnected itself from Rome completely. By that time, missionary influence had led to a new Uniat line in Diyarbakir (Amida). Its first patriarch took the name of Yosep (1681-96). The patriarchs of Rabban Hormizd repeatedly tried to establish closer links with Rome, but only in the early nineteenth century did this lead to Roman Catholic recognition of its last patriarch, Yukhannan Hormizd. In 1830, after Yosep V Augustin Hindi of Diyarbakir had died, this Yukhannan Hormizd became the sole

${ }^{5}$ I am greatly obliged to Dr. J.F. Coakley for his willingness to share this information with me, as well as for his constructive remarks concerning other aspects of the present article. 
Uniate, i.e. Chaldean, patriarch "of Babylon."” Here lies the origin of the present Chaldean patriarchate of Babylon, which now has its see in Baghdad. The late successors of Sulaqa, who around 1600 discontinued their connection with Rome, re-introduced hereditary succession in the Shimun-line. The patriarchate of the present-day Assyrian Church of the East, with its see in Chicago (Illinois, USA), forms the continuation of this line. Upon the election of the present patriarch, Mar Dinkha IV, in 1976, hereditary succession was abandoned once again. For completeness' sake, I have added the names and dates of the patriarchs up to the present day, without further critical evaluation or references to manuscripts.

An important aspect of the history of these various patriarchal lines is formed by the geographical distribution of the areas of their jurisdiction in the course of time. I have added three maps displaying the changing regions of jurisdiction of the two or three patriarchates: Map A: 1553-90, Map B: 1590-1660, and Map C: 1660-1800. Anyone studying the present contribution will understand that an exact description of these patriarchal regions is impossible to make. I, therefore, assigned two shades of the same color to every patriarchate: the darker one for the area (usually a single location) for which sound manuscript evidence exists (referred to in the text), the lighter shade for the surrounding areas that can be assumed, on the basis of circumstantial evidence, to have formed part of the region of that particular patriarchate. Note further that from 1760 onwards, Catholicism is making its way into the region of the patriarchs of the Abuna family. This is not indicated in map C, since usually these "Catholic" mss. claim adherence to the Abuna family. ${ }^{7}$

All entries, if possible, contain the following items:

- Name and "number" of the patriarch, followed by the dates of his patriarchate. My enumeration follows that of Lampart 1966, and differs from Tisserant and Fiey as to the numbering of the Eliya line. The latter assume two different Eliyas during the reign of Eliya VI (1558-91). Note that this numbering differs in a

${ }^{6}$ For the designation "patriarchate of Babylon," see De Vries 1960: 46 and Lampart 1966: 48-9. Both argue that in this period "Babylon" does not necessarily refer to a patriarchal see in the city of Baghdad.

${ }^{7}$ Fiey 1965 and 1977, Sanders 1978 and 1997, as well as the maps in Wilmshurst's unpublished thesis (1998), helped me in locating most of the towns and villages mentioned in the manuscript colophons. 
number of cases from the traditional numbering within the Assyrian Church of the East (cf. Coakley, "patriarchal list").

- Place of residence: in many cases only a single reference is found. A name here indicates that the patriarch lived there for at least a certain period. This does not exclude the possibility of other places of residence.

- Roman Catholic connections: indications concerning correspondence with Rome, contacts with RC missionaries, or an official recognition by the Pope. For further information on this subject, see Giamil 1902, Tisserant 1931, Beltrami 1933, and Lampart 1966.

- Burial place, mainly based on Vosté 1930a.

- Natar kursi (designated successor). Note that the name of the natar kursi is not always identical to the name of the following patriarch. There are various reasons for this: the patriarch might have designated another natar kursi after the first one died or fell out of grace, or the natar kursi is known only by the traditional name of his episcopal see, a name which usually was not kept on becoming patriarch. Usually the natar kursi was a nephew of the patriarch, sometimes a younger brother.

- Manuscript attestations: references to ms. colophons in which a patriarch is mentioned are given here. The number of attestations is rather uneven. During the time of some patriarchs many mss. were written and have been preserved, whereas other periods have yielded almost nothing. Note further that most references in colophons are to a patriarch "Eliya" or "Shimun," without further designations. Such attestations can be linked to a certain patriarch only by the date of the manuscript.

In case of scholarly disagreements concerning the history of certain patriarchs, the present discussion will be summarized in a smaller type. References to a few relevant studies on individual patriarchs can be found here as well, but a full bibliography on patriarchal succession in this period is beyond the scope of the present article.

As to the transcription of Syriac names: a purely scholarly transcription is almost impossible due to the constraints of internet type founding, and also would do no justice to the considerable differences between the scholarly transcription of Classical Syriac and the pronunciation of Syriac (both Classical and Modern) in the period under discussion. On the other hand, a purely phonetic rendering would make some names hardly recognizable to the scholar used to traditional transcriptions. Therefore I adopted a 
middle road between these two extremes, using Anglicized renderings of modern Syriac pronunciation, making use as much as possible of traditional transcription standards.

\section{Patriarchate of Rabban Hormizd (BAR MAMA OR ABUNA FAMILY)}

Shimun IV Basidi, [1437] - 20 Feb. 1497

Place of residence: Rabban Hormizd?

Burial place: Tombstone in Rabban Hormizd (Vosté 1930a: 283-5).

natar kursi: Eliya, metropolitan of Mosul, nephew of Shimun Basidi.

Ms. attestations: a.o., Seert 119 (Athel, June 6, 1437), Mardin 1 (Mar Augin 1486), Mardin 13 (Gazarta 1488), Berlin 38 (n.p., 1496).

Kawerau (1955: 119), referring to Graf 1949 (3): 62, gives 1437-77 as the period of his reign, and mentions a decree of this patriarch issued in 1450 by which he supposedly started hereditary succession within the Bar Mama / Abuna family. Tisserant (1931: 228) and Lampart (1966: 51-2) also mention this decree, the latter basing himself on Giamil (1902: 544). However, none of these authors seems to have a written source for this assumption. Wilmshurst (1998: 165) notes that the date of Shimun's rise to the patriarchate is uncertain, and that he might have been in office as early as in $1429 / 30$, when a patriarch Shimun is referred to in Paris 184. This would make for an exceptionally long reign of sixty-eight years.

Shimun's epitaph (Vosté 1930a: 283-4) suggests that it was written by a Mar Khnanishu. This Khnanishu might have succeeded Eliya as natar kursi before Shimun IV died, and subsequently have become Shimun V, but he might also have been installed as natar kursi after Shimun IV's death. Then he should be considered as Simun V's natar kursi (so Wilmshurst 1998: 87).

Shimun V, 1497 - Sept. 1502

Place of residence: Gazarta d-Bet Zabday (Jezira). Burial place: No tombstone. He was buried in the monastery of Mar Augin, near Gazarta.

natar kursi: Khnanishu? (cf. above).

Ms. attestations: Vat. 204 (no colophon, but containing a note of 1532), Paris 25 (Malabar 1503/4), Diar. 102 (Mar Augin, 1500/1). 
The existence of Shimun V, who appears in all patriarchal lists (e.g., Tisserant and Fiey), seems to be contradicted by one of our main sources for the history of this period, The History of the Christians of Malabar (Assemani BO iii,1(a): 589-599, Vat. 204; for an English translation, see Mingana 1926: 468ff. Another ms. containing this story is Berlin 59, which Sachau thinks originates in the Urmia region, first half 18th c.). This source tells us that Syrians from India came to visit Mar Shimun in 1489/90 in Gazarta, that Mar Shimun consecrated bishops for the Indian dioceses, that bishop Mar Thoma on a second visit witnessed Shimun's death and burial in 1501/02 in Mar Augin, and further dealt with Mar Shimun's successor Eliya in 1502/3. The latter died "a year later," thus in 1503/4, after a letter had been written from India about the arrival of the Portuguese. A second attestation to the succession by Eliya is found in Paris 25 (1504), fo. 7 [transl. Mingana 1926: 473]: "Let it be known also that in the year 1813, at the beginning of the month September (thus Sept. 1502), our common Father, Mar Simon, the Catholicos of the East, left this world of miseries" (Mingana here bases himself on Nau 1912: 82-3, who edited the colophon of Paris 25. This colophon is not in Zotenberg's catalogue).

While these two references both testify to the fact that a patriarch Shimun died in 1502 in the Gazarta area and was succeeded by Eliya, the first source creates ambiguity as to the length of his predecessor's reign. The story suggests that the patriarch whom the Syrians of India met in $1489 / 90$ was the same as the one who died in 1501/2. However, the death of Shimun IV in 1497 is attested to by a funeral inscription in Rabban Hormizd, and therefore he cannot have been the Shimun the Indian Syrians met in 1501/2. Although one might consider the possibility that an otherwise unattested counter-patriarchate existed in Gazarta, which opposed the patriarchate in Rabban Hormizd, I propose another solution. The History tells that the second visit took place only a "short time" (zabna qalli) after the first. When one takes into account the time needed for travel in these days, "a short time" might perhaps refer to a few years, but is unlikely to denote the more than ten years that elapsed between the first and second visit. I suggest therefore that the date of the first visit needs emendation. The easiest solution might be to read "1811" (1499/1500), rather than "1801."

Eliya V, 1502-4

Place of residence: Gazarta, monastery of Mar Yukhannan the Egyptian.

Burial place: No tombstone. Attested to in The History of the Christians of Malabar (cf. above); according to this account he was buried in the church of Miskinta in Mosul. 
Ms. attestations: Vat. 204, Paris 25 (cf. above).

We do not know the precise date of Eliya's death, but the above mentioned colophon of Paris 25 (Nau 1912) states that Eliya consecrated metropolitans and bishops for India, in the monastery of Mar Yukhannan the Egyptian near Gazarta Zabdayta, on April 8, 1504.

Shimun VI, 1504 - 5 August 1538

Place of residence: Rabban Hormizd

Burial place: Tombstone in Rabban Hormizd, written by Qasha (priest) Israel (Vosté 1930a: 286).

natar kursi: Ishuyau, probably metropolitan of Mosul, brother of Shimun VI.

Ms. attestations: Diar. 5 (Mar Akha 1528), Vat. 91 (Mar Augin 1530), Mardin 12 (Gazarta 1536).

Wilmshurst (1998: 87, 165), suggests that Ishuyau succeeded his brother late in 1538 or early in 1539 , because he is referred to as natar kursi in a ms. of October 1538.

\section{Map A: \\ Two patriarchates (1553-90)}

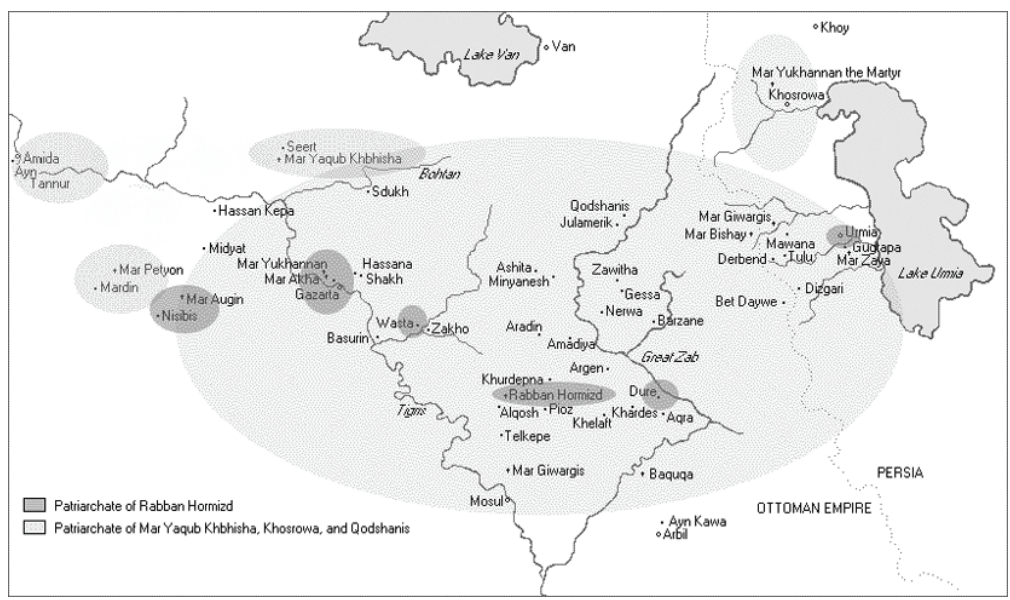

[12] Shimun VII Ishuyau bar Mama, 1538/39 - 1 Nov. 1558 $\{$ MAP A\}

Place of residence: Rabban Hormizd.

Burial place: Tombstone in Rabban Hormizd (Vosté 1930a: 286-7). 
natar kursi: Khnanishu, nephew of Shimun VII, who was succeeded as natar kursi by his brother Eliya in 1550 (Wilmshurst 1998: 87).

Ms. attestations: Among many, Diar. 15 (Mar Akha 1540), Mardin 14 (Gazarta 1543), Diar. 53 (Mar Augin 1552), Diar. 50 (Mar Augin 1553), Mardin 38 (Mar Augin 1554), C-Add 1988 (Rabban Hormizd and Mar Augin, Oct. 1558).

Tisserant, Tfinkdji, and Fiey postulate another Shimun (VIII Denkha) to have succeeded Shimun VII in 1551/2, in order to understand Sulaqa's opposition as a discussion over succession after Shimun bar Mama's death rather than as revolt against a patriarch in office. The arguments put forward in Habbi 1966 and Lampart 1966: 50-5 convincingly prove that no "Shimun VIII" succeeded Shimun bar Mama in 1551/2. Beltrami (1933: 81) mentions that Shimun VII traditionally is called qatul, "murderer," but this is not reflected in the mss.

Wilmshurst (1998: 87), on the basis of further mss, notes that Khnanishu was the son of priest Giwargis, and was metropolitan of Mosul till he became metropolitan of Gazarta sometime between 1542 and 1545. The consecration of his brother Eliya as natar kursi in 1545 might be due to Khnanishu's death.

Eliya VI bar Giwargis, 1558/9 - 26 May 1591 \{MAP A\}

Place of residence: Rabban Hormizd.

Roman Catholic connections: Chronicle 1939:

390 mentions a letter of 1586 to Rome.

Burial place: Tombstone in Rabban Hormizd.

He died after having been metropolitan for fifteen years and patriarch for thirty-two years (Vosté 1930a: 271, 288-90).

natar kursi: Khnanishu, brother of Eliya VI, and Ishuyau.

Ms. attestations: a.o., Seert 53 (Gazarta 1566), Mosul 55 (Gazarta 1567/68), Berlin 35 (Gazarta Zabdayta 1561), Berlin 82 (Rabban Hormizd 1562), Diar. 84 (Nisibis 1575), C-Add 1975 (Wasta 1586).

Tisserant and Fiey list two Eliyas in this period, the first of whom died in 1576 (probably basing themselves on Giamil). Their reasons for this are unclear, whereas the funeral inscription in Rabban Hormizd is unambiguous as to Eliya VI's time of reign. 
Bishop Yosep of Urmi dedicated a funeral hymn to this patriarch; see BNF 371.VII (no place or date) and Mosul 40 (Mar Quriaqos in Dure 1599/1600).

Wilmshurst (1998: 87) mentions a second natar kursi, referred to in 1588 , by name of Ishuyau. It is unclear whether either of these two is identical to Eliya VII.

\section{Map B: \\ Shifting allegiances (1590-1660)}

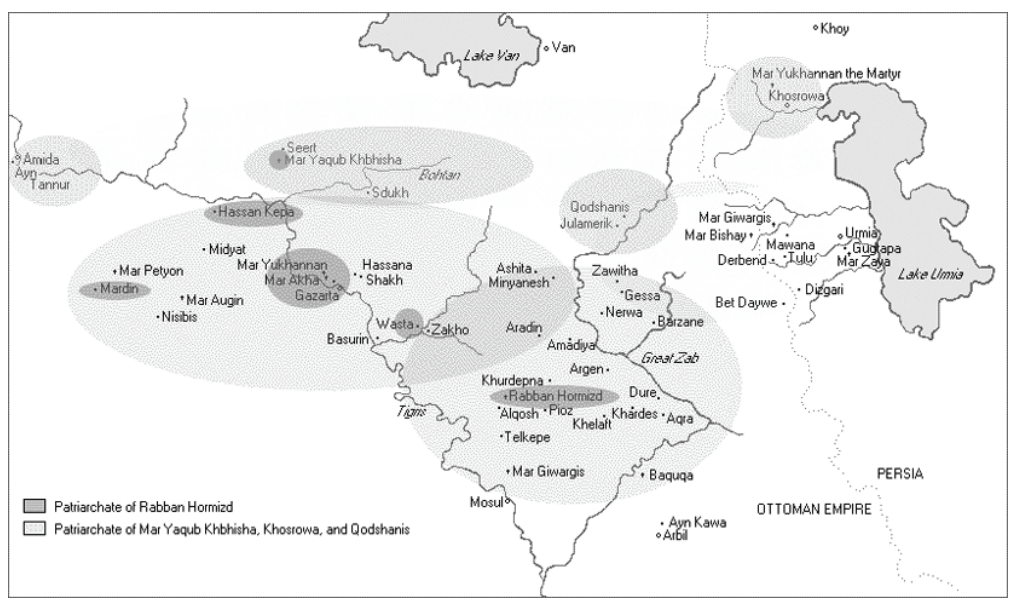

Eliya VII, 1591 - 26 May 1617 \{MAP B

Place of residence: Rabban Hormizd.

Roman Catholic connections: Eliya VII sent emissaries to Rome in 1606 and 1607, and sent his archdeacon Adam in 1611. Eliya further convened an "Unionssynode" in 1616, which, however, did not result in a real union (Lampart 1966: 66-7).

Burial place: Tombstone in Rabban Hormizd (Vosté 1930a: 290-91).

natar kursi: Shimun, Khnanishu.

Ms. attestations: a.o., Mardin 90 (Gazarta, Nov. 1591, Arabic), Alqosh 22 (Gazarta 1599), Diar. 75 (Wasta 1609), Seert 34 (Mar Yaqub Khbhisha, April 1611), Seert 90 (Mar Yaqub Khbhisha 1612).

Note that the colophon of Seert 34 actually mentions two patriarchs: Mar Eliya and Mar Shimun. Wilmshurst (1998: 88) points to a second natar kursi, named Khnanishu, who is mentioned in a list of clergy of 
1610, and further in 1614 and 1617, basing himself on Giamil 1902. The use of the name Shimun for Eliya VIII suggests that he is traditionally identified with the first natar kursi.

Eliya VIII Shimun, 1617 - 18 June 1660 \{MAP B

Place of residence: Rabban Hormizd, Telkepe in times of Kurdish unrest (Chronicle 1939: 391).

Roman Catholic connections: Contacts with RC missionaries in 1619,1629, 1638 and 1653, but no union.

Burial place: Tombstone in Rabban Hormizd, died after forty-three years in office (Vosté 1930a: 291-2).

natar kursi: Khnanishu.

Ms. attestations: a.o., Seert 6 (n.p., 1625), Mardin 86 (Hassan Kepa 1628, Arabic), Diar. 90 (Mardin 1635), Assfalg 34 (Rabban Hormizd 1649).

No ms. attestations of a natar kursi have been encountered. According to Coakley (private correspondence) Giamil (1902: 186) mentions the name of Khnanishu.

\section{Map C: \\ A third patriarchate (1660-1830)}

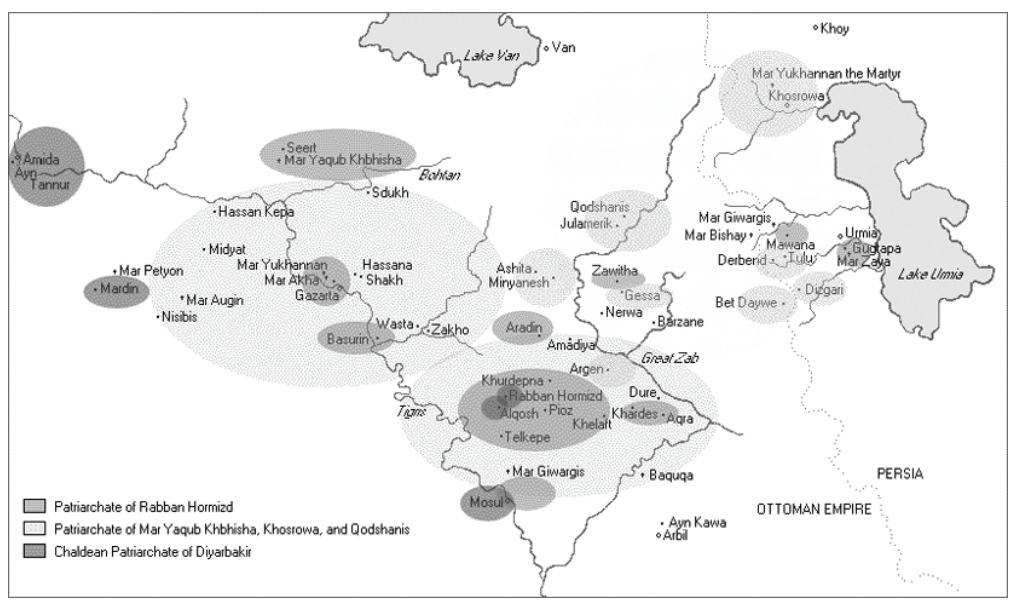


Eliya IX Yukhannan Maraugin, 1660 - 17 May 1700 $\{$ MAP C $\}$

Place of residence: Rabban Hormizd.

Roman Catholic connections: Attempts at union between 1666 and 1670, and from 16921694, but no union resulted from this.

Burial place: Tombstone in Rabban Hormizd, died after forty years in office (Vosté 1930a: 292-4).

natar kursi: Ishuyau.

Ms. attestations: among many others: C-Or 1145 (Gazarta Zabdayta 1661), L-Or 8678 (Rabban Hormizd 1669), Mingana 489 (Alqosh 1674), Alqosh 325 (Bassuri on the Tigris 1680), Alqosh 17 (Araden 1683), C-Or 1295 (Gazarta d-Zabdayta 1685), C-Add 2045 (Mawana and Mar Zaya in Gugtapa, 1685/6), C-Add 2020 (Alqosh 1697), BNF 424-425 (Alqosh $1900>$ Alqosh 1699).

Wilmshurst (1998: 88) refers to two other natar kursis: Shimun in 1669 (cf. Giamil 1902: 540, no ms. attestations) and David, in a colophon of 1679. Ishuyau, the future patriarch, is attested to from 1693 onwards.

Eliya X Maraugin, 1700 - 14 December 1722 \{MAP C\}

Place of residence: Rabban Hormizd, Telkepe.

Roman Catholic connections: uncertain, probably none ( $f$. Lampart 1966: 213).

Burial place: Tombstone in Rabban Hormizd, was in office for twenty-three years (Vosté 1930a: 294-6).

natar kursi: Ishuyau and Khnanishu.

Ms. attestations: a.o., Mosul 2 (Alqosh, 1700/01), Seert 47 (Seert 1702), Aqra 52 (Alqosh, Nov. 1700), Mingana 595 (Telkepe 1717), L-Or 4416 (Telkepe 1720), L-Or 4069 (Alqosh 1721/22).

Ishuyau is mentioned as natar kursi in Mosul 2, and, according to Wilmshurst (1998: 88), in a ms. of 1712. Khnanishu is mentioned as natar kursi in L-Or 4416. 
Eliya XI Denkha, 1722 - April 1778 \{MAP C

Place of residence: Rabban Hormizd, later Alqosh and perhaps Mosul.

Roman Catholic connections: letters, some with confession of faith, to Rome in 1735, 1749, 1750, 1756, and 1771, but no formal recognition resulted.

Burial place: No tombstone in Rabban Hormizd, Eliya XI is said to have died of the plague (Vosté 1930a: 296). According to Fiey (1965: 546), Rabban Hormizd was destroyed by the troops of Nadir Shah in 1743 and remained in ruins for sixty-five years. Whether the two patriarchs that were buried here during this period actually lived in the monastery therefore is uncertain.

natar kursi: Ishuyau.

Ms. attestations: a.o., C-Add 1980 (Alqosh 1722/23), C-Add 2889 (Mosul 1730), Mingana 567 (Zawitha d-Tiari 1744), Mingana 568 (Khardes 1757), Aqra 54 (Alqosh 1766), Aqra 45 (Alqosh 1777).

Three different days in April are mentioned as the date of Eliya's death: April 12 (Tisserant and Lampart 1966: 64) April 20 (Tfinkdji, Vosté), April 29 (Yukhannan Hormizd in Badger 1852, 1:151). The modern authors do not refer to a contemporary source, and therefore Badger's translation of Yukhannan Hormizd's autobiography, nephew and natar kursi of the deceased, might well be most reliable.

Wilmshurst (1998: 88) mentions a natar kursi Ishuyau as early as 1726. Since natar kursi Ishuyau who was to became Eliya XII was consecrated metropolitan c. 1744 (cf. below), Wilmshurst suggests that two different Ishuyaus existed. The second natar kursi Ishuyau was replaced in 1776 by his younger cousin Yukhannan Hormizd, after Ishuyau fell out of grace (so Yukhannan's autobiography in Badger 1852, 1:151). However, a manuscript dated to the last year of Eliya XI's reign, Aqra 45 (Alqosh 1777) mentions Ishuyau as metropolitan. This does not necessarily mean that Yukhannan Hormizd was not consecrated metropolitan in 1776, but it does indicate that at least this one scribe in Alqosh thought Ishuyau more important than Yukhannan Hormizd. 
Eliya XII Ishuyau, 1778-1804 \{MAP C

Place of residence: Rabban Hormizd? (see under Eliya XI).

Roman Catholic connections: Eliya XII had joined in one of his predecessor's confessions (1749?), and he himself wrote to Rome in 1779. No formal union resulted from either one of these attempts.

Burial place: Tombstone in Rabban Hormizd (Vosté 1930a: 296-8). According to this tombstone, Eliya XII served as metropolitan Ishuyau for thirty-four years before his rise to patriarchate.

natar kursi: Ishuyau and Khnanishu.

Ms. attestations: so far none dating to the period of his patriarchate. Ishuyau is known as a copyist in the years preceding his patriarchate, so Mosul 10 (Alqosh 1752/3) and C-Add 2021 (Alqosh? 1776).

Not much is known about Eliya XII, but cf. Tfinkdji 1914: 462 and Tisserant 1931: 256. Most important is the fact that his reign was vehemently opposed to by Yukhannan Hormizd, his cousin, who apparently was consecrated by Eliya XI as well. Most of their quarrels concerned their respective connections to Roman Catholicism. Wilmshurst (1998: 88) adds to this information that Eliya XII was the son of priest Auraham, who was the son of priest Khadbshabba.

In line with Tisserant (1931: 256), I take the two letters that were edited by Babakhan (Babakhan 1900), as letters by Eliya XII, rather than by Eliya XI, as Babakhan's introduction seems to suggest. The main difficulty for my suggestion is the fact that in the second letter, to Mar Shimun [XV] of Qodshanis, a synod is mentioned that was convened by the author, the patriarch of the East, and attended to, a.o., by his natar kursi Ishuyau. This would imply that Eliya XII Ishuyau installed a natar kursi Ishuyau immediately after his rise to the patriarchate. Other elements of these letters, such as the date of October 1779 and a reference to his predecessor who wrote to Rome in 1756, strongly suggest that the author is indeed Eliya XII. When written by Eliya XII, both letters testify to his wish to re-establish contact with Rome, perhaps in reaction to Yukhannan Hormizd's conversion to Catholicism following the death of Eliya XI. Wilmshurst (1998: 88) mentions a natar kursi Khnanishu, a nephew of Eliya XII, in 1784. 


\section{Yukhannan VIII [Eliya] Hormizd, 5 July 1830 - 16 August $1838\{$ MAP C}

Place of residence: Rabban Hormizd, Mosul and Baghdad.

Roman Catholic connections: Yukhannan Hormizd considered himself a Roman Catholic from 1778 onwards (Badger 1852, 1:151), but he had difficulties in being accepted by Rome as a suitable candidate for the patriarchate. It was only in 1830, after Augustin Hindi (Yosep V) had died, that he was officially recognized by Rome (Tfinkdji 1914: 462-3).

Burial place: No tombstone in Rabban Hormizd. Ms. attestations: Ming 94 (Alqosh, Sept. 1803) refers to Mar Yukhannan patr. of the East, the head (rumrama) of the Catholics. A later ms. (CAdd 2812, Alqosh 1806) refers to Mar Yukhannan only with the title of metropolitan, whereas Aqra 21 (Alqosh 1809) refers to him as patriarch. Aqra 10 (Barzane 1813) and Strasb. 4118 (n.p. 1824) mention a patriarch Eliya, which in all likelihood refers to Yukhannan Hormizd as well.

Yukhannan Hormizd wrote his autobiography in Classical Syriac (Cambridge Add. 2919, c. 1830, incomplete), and this text was translated by the Anglican missionary George Percy Badger and published in Badger 1852, 1:150-60. Interesting as this account is, it is also a highly polemical account, the data of which need to be treated with care. This part of his autobiography (Badger's translation is incomplete) covers the period up to 1795, when Yukhannan's main opponent was Eliya XII. In later years, after Gabriel Danbo had re-established a monastic order in Rabban Hormizd, Yukhannan Hormizd had to face opposition from this side, especially since the monks accepted the Chaldean Yosep V in Diyarbakir as their patriarch (cf. Bello 1939). The rest of Yukhannan Hormizd's story is told by Badger himself, and it is somewhat difficult to reconcile his elaborate version with the data in other sources, especially since he hardly gives any dates. He mentions Yukhannan's official recognition by Rome "as supreme head over all the Chaldeans" (Badger 1852, 1:164), which event perhaps should be equated to the recognition dated to 1830 by Tfinkdji and others, but Badger also refers to Yukhannan receiving the pallium in Baghdad, "little more than a year before his death, which took place in that city, A.D. 1841" (Badger 1852, 1:167). According to all other 
sources (which seem to base themselves on Giamil), Yukhannan Hormizd died in 1838.

Kawerau (1955-6: 128-9) tentatively suggests the existence of a later patriarch Eliya (Eliya XIV, in his counting), who is attested to in writings of American missionaries around 1831. However, De Vries (1960) convincingly shows that it is rather unlikely that such a patriarch existed. The missionaries might have met with a metropolitan Eliya, whereas other information on "Patriarch Eliya" might in fact refer to Yukhannan Hormizd, who apparently used the name Eliya (cf. Badger 1852, 1:150, and the ms. colophons mentioned above).

\section{Patriarchate of Mar Yaqub Khbhisha, KHOSROWA, AND QODSHANIS}

Yukhannan Sulaqa, 28 April 1553 - January 1555 \{MAP A\}

Place of residence: Diyarbakir (Amida).

Roman Catholic connections: early in 1552, Sulaqa, monk of Rabban Hormizd since c. 1510 and abbot since c. 1540, was elected patriarch by part of the East Syrians. Sulaqa traveled to Rome for consecration and papal recognition. He made his profession of faith on 15 February 1553, which was recognized on 20 February 1553. He was confirmed as patriarch on 28 April 1553 (Habbi 1966: 108-9, Lampart 1966: 50-6).

Burial place: Sulaqa died in prison.

Ms. attestations: so far, none.

Whether Sulaqa did indeed use the name Yukhannan is not certain. It is found in Audishu IV's poem on Sulaqa and in an unclear reference by Eliya Asmar Habib (Vosté 1931, Habbi 1966: 104-5). In the same source, Audishu refers to Bet Qoqa (Baquqa) as Sulaqa's monastery. All other sources mention Rabban Hormizd (cf. Fiey 1965: 156). Note further that in Arabic, Sulaqa's name is rendered as Su'ud, whereas after his consecration in Rome Sulaqa was officially called Shimun VIII, patriarch of Mosul (Habbi 1966: 104-5, Lampart 1966: 55).

Audishu IV Yukhannan, 1555 - 11 Sept. 1570 \{MAP A\}

Place of residence: Mar Yaqub Khbhisha near Seert.

Roman Catholic connections: Audishu, a former monk of the twin monasteries of Mar 
Akha and Mar Yukhannan (Baumstark 1922: 333, Beltrami 1933: 59-66), was one of the bishops that were consecrated by Yukhannan Sulaqa, in an attempt to secure Catholic succession. Audishu traveled to Rome to obtain papal recognition, in which he succeeded in 1562. Tfinkdji (1914: 457) suggests that Audishu attended the Council of Trent on 4 Dec. 1563, but no other sources confirm this. Beltrami (1933: 62-3) notes that Audishu's confession of faith was discussed at this Council in September 1562.

Burial place: Mar Yaqub Khbhisha?

Ms. attestations: a.o., Diar. 111 (Amida 1563), Seert 15 (Mar Yaqub Khbhisha, Oct. 20, 1569), Diar. 60 (Mar Petyon 1571). Note further that Audishu was a prolific author whose poems appear in many later mss. (Baumstark 1922: 333).

There is some uncertainty as to the date of Audishu's death. Lampart (1966: 57-8) suggests that Audishu died in 1567. He bases himself on Beltrami (1933: 66, 199-203), who quotes a letter by Eliya [Asmar Habib] of 1581, telling us that Audishu died after reigning for twelve years, "al fine di dodici anni del suo patriarchato morse nel monasterio di S. Giacomo in Scerte." Tisserant (1931: 263) sets his death "early 1571," probably basing himself on Diar. 60 (Mar Petyon 1571), whose copyist refers to patriarch Audisho, "qui vient de mourir" when he completed the ms. 11 May 1571 (1882). Baumstark (1922: 333) gives a precise date of Audishu's death: 11 September 1570. The source for his date must be Mosul 63. This otherwise undated ms. contains a note stating that Audishu died 11 Sept. 1881 AG, thus 1570 AD. Given the fact that Audishu himself completed a manuscript October 20,1569 (Seert 15, Mar Yaqub Khbhisha) and that therefore Lampart's interpretation of the twelve years of Audishu's reign does not hold, the precise date of Mosul 63 seems most likely. This date suggests that Eliya, in the letter as quoted in Beltrami perhaps counted Audishu's reign from a starting point somewhere in 1558. This covers the early period of Audishu's visit to Rome searching for papal recognition (1559-62), but not his formal recognition that took place only in 1562 (Lampart 1966: 57).

Assuming that Audishu's death in 1570 is sufficiently established, another ms. from this period presents a problem: Mardin 37 (Mar Petyon, Oct. 1568), was written during the time of a patriarch Shimun with a natar kursi Mar Eliya and a Mar Eliya metropolitan of Amida. No Mar Shimun with a natar kursi Eliya is known to have been in office in 1568 (Shimun 
VII Bar Mama died in 1558). The copyist of this ms, Mar Khnanishu, metropolitan of Mardin, in most of his other mss. (1565-72) does not acknowledge any patriarch, whereas in a ms. of 1564 he acknowledges Mar Audishu, with rather elaborate praises. Wilmshurst (1998: 35), suggests that this bishop converted to Roman Catholicism in the early days of his career and remained loyal to Audishu and his successor YauAlaha Shimun.

Shimun [Yau-Alaha?], 1572-76 \{MAP

Place of residence: Mar Yaqub Khbhisha.

Ms. attestations: Vat. 472 (Mar Yaqub Khbhisha

1572), Diar. 88 (Amida 1574).

In current patriarchal lists, the patriarchal see is said to have been vacant after Audishu. Yau-Alaha, who had been consecrated bishop by Audishu, supposedly acted as administrator ad interim until his consecration as patriarch in 1572 (Lampart 1966: 58). However, two mss. refer to a Mar Shimun being in office in 1572 and 1574 (see above), whereas Wilmshurst ascribes two further mss. to a patriarch Shimun in this period (Wilmshurst 1998: 14). The second of these (Karam 331, in the Ashurbanipal Library, Chicago) is dated to 1576. This Shimun might either be a patriarch who never officially was recognized among a larger part of the Chaldeans, or might in fact be Yau-Alaha himself, who seemed to have used the name Shimun (cf. Beltrami 1933: 200, referring to a letter of 1581: "patriarcha Mar Aath Alla Simone," and also Wilmshurst 1998: 14). A third possibility is that these mss. refer to Shimun IX, who succeeded Yau-Alaha in 1579, and perhaps, although there is no further evidence for this, opposed Yau-Alaha during his interim years.

The traditional list L2 in Coakley's "Patriarchal list" refers to a patriarch Shimun Yau-Alaha, in office from 1558 to 1580. This reference, although the dates are obviously wrong, might support the identification of Shimun with Yau-Alaha.

Yau-Alaha Shimun (Aath Alla), 1577-79/80 \{MAP A\}

Place of residence: Mar Yaqub Khbhisha.

Roman Catholic connections: Yau-Alaha was consecrated bishop of Gazarta by Audishu. He was probably elected patriarch only around the year 1577, and due to his advanced years was not able to go to Rome. He never obtained official papal recognition.

Ms. attestations: no mss. refer to Yau-Alaha. Perhaps the mss. mentioned under Shimun (1572- 
1576, cf. above) should be considered as referring to Yau-Alaha. It is noteworthy that two other mss. that were written in Mar Yaqub Khbhisha in 1573 (Seert 116 and BNF 371.I), thus after Audishu's death, do not refer to any patriarch at all, as far as can be deduced from the descriptions in the catalogues.

Not much is known about this patriarch, and the various sources contradict each other at some points. Tfinkdji (1914: 457), basing himself on Giamil, mentions that Yau-Alaha was consecrated bishop in 1556 (a date not found in any other source), and that he was elected patriarch right after Audishu's death in 1567. As Audishu probably died only in 1570 , it is likely that Tfinkdji and Giamil did not have any independent sources for this date. Lampart (1966: 58) and Beltrami (1933: 64-8) think that he was elected in 1577, after having served as administrator ad interim. Tisserant (1933: 230) gives 1578 as the date of his election and 1580 as the date of this death, whereas Lampart and Beltrami place his death in 1579. Wilmshurst (1998: 14) places his death in 1580.

Shimun IX Denkha, 1580-1600 \{MAP B

Place of residence: monastery of Mar Yukhannan the Martyr near Salmas.

Roman Catholic connections: Shimun Denkha was bishop of Jelu when he converted to Roman Catholicism. He was elected patriarch shortly after Yau-Alaha's death. His metropolitan, Eliya Asmar Habib, traveled to Rome and secured papal recognition for him in 1581. Due to Eliya's death in 1582 and difficulties on the way, official recognition reached Shimun Denkha only in 1585 (Tfinkdji, Tisserant 1930: 232, Lampart 1966: 58).

natar kursi: there is no mentioning of a natar kursi, but Tisserant suggests that after Shimun IX's death, hereditary succession was taken up again. It is uncertain whether Shimun IX himself had consecrated a suitable nephew, or that a family member was chosen after his death (Tisserant 1933: 230).

Ms. attestations: so far only L-Or 6719 (Khosrowa 1598).

For a discussion of the exact location of the monastery of Mar Yukhannan the Martyr, see Beltrami 1933: 243 and Lampart 1966: 59. See also Wilmshurst 1998: 152. The location of the monastery in my map is no more than a rough guess. It is interesting to note that the copyist of 
L-Or 6719 calls Shimun the patriarch of the East and "of all the earth" (wa-d-kullab tibhel).

Shimun X, 1600-38 \{MAP B\}

Place of residence: Khananis and/or Qodshanis.

Roman Catholic connections: correspondence with Rome and contacts with Latin missionaries, which in 1619 led Shimun $\mathrm{X}$ to sign a profession of faith. This did not result in official recognition (Tisserant 1931: 230-1, Lampart 1966: 61, 229).

natar kursi: Mar Ishuyau (Seert 46).

Ms. attestations: a.o., Seert 46 (Mar Yaqub Khbhisha 1604), Seert 54-55 (Sdukh 1610), Seert 34 (Mar Yaqub Khbhisha 1611).

A letter by Shimun X to the Pope (Doc. I, July 1619, Lampart 1966: 229), mentions as his place of residence: "Cananes terra di Zacharia Abach Prencipe de Curdi." Lampart (1966: 61) identifies "Cananes" with Qodshanis, but a nineteenth-century quotation in Coakley (1992: 258) makes clear that Khananis is a different village, about 10 kilometers south of Qodshanis (see also his map, p. 8-9). This is confirmed by the spelling Xananis in Mingana 148 (Nerwa 1613). Unfortunately no patriarch is mentioned in this colophon.

Note that so far Seert 34 is the only ms. mentioning a natar kursi in the Shimun line. All following Shimuns must have consecrated natar kursis, but these are not mentioned in the mss. The colophon of this ms. mentions two patriarchs: Mar Shimun and Mar Eliya, which perhaps reflects a period of good relationships between the two lines.

According to Wilmshurst (1998: 168) it was this patriarch that reverted to the "old faith." Wilmshurst (1998: 131) further mentions that this patriarch at some times is "associated with" the monastery of Mar Yukhannan in Salmas, alongside his usual residence in Qodshanis.

Coakley, "Eliya of Alqosh," has different dates for the patriarchs of this line. For Shimun X, the dates are 1600-1639. As we have hardly any independent evidence for the dates in the lists of Tisserant, Tfinkdji, and Fiey, Eliya's list might be as reliable as any other.

Shimun XI, 1638-56 \{MAP B\}

Place of residence: Qodshanis, from 1649/50: Khosrau Abad (Khosrowa).

Roman Catholic connections: Shimun XI sent professions to Rome in 1648 and 1653, but this did not 
result in official recognition (Lampart 1966: 233, n. 1, Baumstark 1922: 324).

natar kursi: unknown.

Ms. attestations: Diar. 32 (Amida, 2 June 1638), Diar. 47 (Amida 1651), Diar. 6 (Amida 1652), Berlin 30 (n.p., 1655).

These four mss. all mention Mar Shimun, metropolitan of Amida, and of the first three we know that they were written in Amida. This might indicate that Diar. 32 was indeed written during the time of Shimun XI, rather than Shimun X, but since we do not know when the latter died, there is no absolute certainty. This Shimun of Amida played an important role in Shimun's connections to Rome, but in 1649 his conversion to Catholicism was no longer thought sincere (Lampart 1966: 231-2). Whether this is the same person as the one mentioned in BNF 381 (Beirut 1636) as having made a profession of faith already in 1627 (Prete Simeoni di Amit') is uncertain.

As to Shimun XI's places of residence, cf. Lampart (1966: 61) and Chronicle (1939: 383). Note further that in Diar. 32 an interesting, but historically unlikely description of Shimun's area of jurisdiction is given, including "Persia, Hamadan, Khelat [Khelaft?], Van and Wastan [Wasta?]."

A letter of 1664 suggests that Shimun XI was removed from office because of his attempts at a union; so Chronicle (1939: 389). No further evidence for this assumption has been found so far. Coakley, "Eliya of Alqosh': 1639-53.

Shimun XII, 1656-62 \{MAP B

Place of residence: Khosrau Abad (Khosrowa).

Roman Catholic connections: some correspondence, among which a letter from Pope Alexander VII in 1661 (Lampart 1966: 62, 233). No official recognition.

natar kursi: unknown.

Ms. attestations: none.

Coakley, "Eliya of Alqosh': 1653-92.

Shimun XIII Denkha, 1662-1700 \{MAP C

Place of residence: Khosrowa, from 1672: Qodshanis.

Roman Catholic connections: letter to and from Rome in 1670 (Lampart 62, 244-5, Doc. XI, unclear reference), but after move to Qodshanis no further connections.

natar kursi: unknown. 
Ms. attestations: C-Or 1293 (Arqe 1666), ${ }^{8}$ Oxford d. 36 (Darband 1680), BNF 393 (Darband [Tergawar] 1695).

Note that C-Add 2045, copied in 1686 partly in Mawana in Tergawar and partly in Mar Zayya in Gugtapa in the region of Urmi, suggests that these areas were under the jurisdiction of Eliya [IX].

According to Mar Eliya of Alqosh, Shimun XIII was related to the Abuna family. However, the relationship between the two branches was not a good one, as Shimun Denkha supposedly murdered Mar Khnanishu, Shimun's cousin and brother of patriarch Eliya IX Yukhannan Maraugin. According to Eliya of Alqosh, this earned him the name Qatola, "murderer." He was in office 1692-1700 (Coakley, "Eliya of Alqosh"). No independent evidence affirms either the family relationship between the patriarchates of Rabban Hormizd and Qodshanis or the murder of Mar Khnanishu.

Shimun XIV Shlimun, 1700-40 \{MAP C

Place of residence: Qodshanis.

natar kursi: unknown.

Ms. attestations: Alqosh 132 (Qodshanis 1731), Oxford f. 9 (place erased, 1727), C-Add 2047 (Khbashakobe [unidentified] in Tergawar, 1728). Cf. also Urmia 109 (1724), written by the scribe Abdalahad of Qodshanis, but without mentioning a patriarch.

Coakley, "Eliya of Alqosh:" 1700-17.

Shimun XV Michael Muktes, 1740-80 \{MAP C\}

Place of residence: Qodshanis.

Roman Catholic connections: Shimun XV wrote a letter to Rome in 1770 (Tisserant 1931: 242, basing himself on Giamil, cf. also Kawerau 1955: 120-1, who gives 1771). No union resulted from this.

Ms. attestations: Berlin 48 (Kartinis in Gawar [unidentified], 1743), Berlin 42 (Jalam [unidentified],

8 I assume that Arqe is identical to Argen, as located by Fiey (1965: 313) and Wilmshurst (1997: map no. 4) in the Talana district, northwest of Aqra. 
Church of Mar Zaya, 1756), Berlin 50 (Dazgiri in Pelgawar, ${ }^{9}$ 1761).

Shimun XVI Yukhannan, 1780-1820 \{MAP C \}

Place of residence: Qodshanis.

natar kursi: unknown.

Ms. attestations: a.o., C-Add 1978 (Gessa of Mar Bar Sabbace, ${ }^{10}$ 1785), Aqra 40 (Bet Daywe in Shapat, 1786), LOr 14407 (Tulu in Tergawar, 1790/91), Alqosh 134 (Gessa in Tkhuma, 1791), C-Add 2037 (Tergawar 1803), Alqosh 135 (Menyanesh 1815), Oxford d. 34 (Balulan in Tergawar unidentified], 1824).

\section{Church of the East Patriarchate}

Shimun XVII Auraham

1820-60 (Qodshanis)

Shimun XVIII Ruben 1860-1903 Qodshanis)

Shimun XIX Benjamin

Shimun XX Paulus 1903-18 Qodshanis)

Shimun XXI Eshay

1918-2011

Denkha IV

$1920-75$

1976 - present (Chicago)

\section{Patriarchate of Mar Yaqub KHbhisha, KHOSROWA, AND QODSHANIS}

Yosep I, 1681-96 \{MAP C

Place of residence: Diyarbakir.

Roman Catholic connections: Yosep converted to Roman obedience c. 1667/8, when he was consecrated bishop. He arrived in Rome in at the end of 1673, returned to Diyarbakir, and received the Papal pallium in 1681 . He returned to Rome in 1694 and abdicated in 1696 (Kawerau 1955/56, wrongly 1693). He died Nov. 10, 1707.

${ }^{9}$ I assume Dazgiri to be identical to Dizgari, located by Wilmshurst (1997: map no. 11) in Mergawar. The district 'Pelgawar' is not in Wilmshurst's map.

${ }^{10}$ Fiey (1965: 194) assumes that Gessa of Mar Bar Sabbace is identical to Gessa in Tkhuma, which is on the map.

${ }^{11}$ For the continuation of the Qodshanis patriarchate in the twentieth century, see Coakley 1996. 
Ms. attestations: Some manuscripts of this period were copied by Qasha Yosep of Bet Ma'ruf who was to succeed Yosep I: Assfalg 2 (Telkepe 1691) and Berlin 53 (Amida 1692). The latter ms. was ordered by Yosep I. L-Eg 703 (Amida 1683) was copied by Yosep I himself.

On Yosep I, see Lampart 1966 (with many original documents), and the Life of Yosep by Abdalahad (Chabot 1896).

Yosep II Sliba Bet Macruf, 1696 - June 2, 1712 \{MAP C\}

Place of residence: Diyarbakir.

Roman Catholic connections: Yosep was born in Telkepe in 1667, where he received first orders at fourteen, and was consecrated as Yosep I's successor in 1694. Papal recognition followed May 21, 1696. He died of the plague in 1712. Yosep II was a prolific writer, both in Classical Syriac and Arabic, and translated many Roman Catholic works into these languages.

Ms. attestations: Mardin 15 (Ayn Tannur 1702).

Cf. further Lampart 1966: 194-6 and 199-200, who bases himself at least partly on autobiographical materials: a letter by Yosep II dated to July 1696 as well as a note in his hand dated to 1703 . Coakley: cholera?

Yosep III Timotheos Maraugin, March 18, 1714-57 $\{$ MAP C $\}$

Place of residence: Diyarbakir, but with long periods of absence between 1729/30 and 1741 .

Roman Catholic connections: He was born either in Kirkuk or in Diyarbakir, raised with the Capuchins in Diyarbakir (Da Seggiano 1962: 391), was consecrated bishop of Mardin in 1696, elected patriarch in 1712, (according to Yosep II's wishes), and received the papal pallium in 1714.

Ms. attestations: Diar. 140 (nt. by Yosep III of 1714), Seert 36 (n.p. [the ms. was ordered in the monastery of Mar Yaqub Khbhisha], 1716), Vat. 606 (Ayn Tannur 1717), C-Add 3218 (Amida 1725). Two other mss. of this period contain work by Yosep II, and therefore may be considered to confirm adherence to the Yosep line: Mardin 97 (Mardin 1715) and Seert 93 (Mosul 1717). 
Kawerau (1955/6: 131) gives as the full name of Yosep III: Yosep Moses Timotheus. For further information on the patriarchs of the Yosep line, see Tfinkdji 1914: 458-60 and Tisserant 1931: 238-43.

\section{Yosep IV Lazare Hindi, 1759-81 \{MAP C\}}

Place of residence: Diyarbakir.

After Yosep III's death in 1757, Lazar Hindi, former pupil of the Propaganda in Rome, was elected patriarch. Confirmation followed in 1759. He abdicated in 1781, appointed his nephew Augustin Hindi as his administrator and possible successor, returned to Rome and died in 1791.

Ms. attestations: Borgia 32 (Ayn Tannur, 1765), Diar. 155 (Ayn Tannur 1766, by Thérèse, daughter of priest Khadjo, 15 years old).

Kawerau 1955/6: 131 has Yosep Timotheus Lazar Hindi as his full name.

Yosep V Augustin Hindi, 1781 - April 6, 1828 \{MAP C\}

Place of residence: Diyarbakir.

Ms. attestations: Ming. 267 (Alqosh 1824), C-Add 1966 (Mosul 1826), Vat. 620 (Mosul 1826). Note further a Rabban Hormizd inscription of 1820, where Yosep is referred to as patriarch qatholiqos (Vosté 1930a: 272-3).

He was appointed administrator in 1781, at that time having received only priestly orders. He became bishop of Diyarbakir in 1804, functioned as patriarch of the Chaldeans, especially of those of the more western areas, but was never fully recognized by Rome, due to the strong opposition by Yukhannan Hormizd. He was recognized, however, by the monks of Rabban Hormizd. Yosep V died in 1828 (Kawerau 1955: 122-7 and Bello 1939: 8-26).

\section{Chaldean Patriarchate}

$\begin{array}{ll}\text { Yukhannan Hormizd } & 1830-38 \\ \text { Nikolas Eshaya } & 1838-47 \\ \text { Yosep VI Audo } & 1848-78 \\ \text { Eliya XIV [XIII] Abulyonan } & 1879-94 \\ \text { Audishu V Khayyat } & 1895-99 \\ \text { Yosep VI Emmanuel II Thoma } & 1900-47 \\ \text { Yosep VII Ghanima } & 1947-58 \\ \text { Paul II Cheykho } & 1958-89 \\ \text { Rhaphael I Bidawid } & 1989-\text { present }\end{array}$




\section{REFERENCES}

\section{Manuscript Catalogues}

Alqosh: J.-M. Vosté O.P., Catalogue de la Bibliothèque syro-chaldéenne du couvent de Notre-Dame des semences près d'Alqass (Iraq), Rome/Paris 1929.

Aqra: J.-M. Vosté O.P., "Catalogue des manuscrits syro-chaldéens conservés dans la Bibliothèque Épiscopale de 'Aqra (Iraq)," Orientalia Christiana Periodica V (1939): 368-406.

Assfalg: Julius Assfalg, Syrische Handschriften; Syrische, Karsunische, ChristlichPalästinische, Neusyrische und Mandäische Handscbriften, Wiesbaden 1963. Verzeichnis der Orientalischen Handschriften in Deutschland, Band V.

BNF: Françoise Briquel-Chatonnet, Manuscrits syriaques de la Bibliothèque nationale de France (nos 356-435, entrés depuis 1911), de la bibliothèque Méjanes d'Aix-en-Provence, de la bibliothèque municipale de Lyon et de la Bibliothèque nationale et universitaire de Strasbourg. Catalogue, Paris 1997.

Berlin: Eduard Sachau, Verzeichniss der Syrischen Handschriften der Königlichen Bibliothek zu Berlin, 2 vols. Berlin 1899. Die HandschriftenVerzeichnisse der Königlichen Bibliothek zu Berlin, Dreiundzwantigster Band.

Borgia: Addai Scher, "Notice sur les manuscrits syriaques du Musée Borgia aujourd'hui à la Bibliothèque Vaticane," Journal Asiatique 13 (1909): 249-87.

C[ambridge] Oo/Add: William Wright, A Catalogue of the Syriac Manuscripts preserved in the Library of the University of Cambridge, 2 vols. Cambridge 1901.

C[ambridge] Or: A.E. Goodman, "The Jenks Collection of Syriac Manuscripts in the University Library, Cambridge," Journal of the Royal Asiatic Society (1939): 595-6. [C-Or 1292-1344].

Diar[bakir]: Addai Scher, "Notice sur les manuscrits syriaques et arabes conservés à l'archevêché chaldéen de Diarbékir," Journal Asiatique X (1907): 331-61, 385-431.

L[ondon] Add/Or/Eg: William Wright, Catalogue of Syriac Manuscripts in the British Museum, acquired since the year 1838, 3 vols. London 1870-2.

L[ondon] Or: G. Margouliouth, Descriptive List of Syriac and Karshuni mss. in the British Museum, acquired since 1873, London 1899 [L-Or 12405463]. Higher numbers of L-Or are not described in published sources, but a typescript list with concise title descriptions is available [L-Or 5604 to L-Or 12073]. Numbers higher than L-Or 12073 refer to the handwritten catalogues in the library. These contain acquisitions since 1959. 
Mardin: Addai Scher, "Notice des mss. syriaques et arabes conservés dans la bibliothèque de l'évêché chaldéen de Mardin," Revue des bibliothèques 18 (1908): 64-95.

Ming[ana]: A. Mingana, Catalogue of the Mingana Collection of Manuscripts, now in the possession of the Trustees of the Woodbrooke settlement, Selly Oak, Birmingham, Vol 1: Syriac and Garshuni Manuscripts. Cambridge 1933.

Mosul: Addar Scher, "Notice sur les manuscrits syriaques conservés dans la bibliothèque du Patriarcat chaldéen de Mossoul," Revue des Bibliothèques 17 (1907): 227-60.

Oxford: Syriac mss. in the Bodleian library, Oxford, in handwritten catalogue (Ms. Syr).

Paris: H. Zotenberg, Manuscrit Orientaux, Catalogues des manuscrits syriaques et sabéens (mandaïtes) de la bibliothèque nationale. Paris 1874.

Seert: Addai Scher, Catalogue des manuscrits syriaques et arabes conservés dans la bibiothèque épiscopale de Séert (Kurdistan) avec notes bibliographiques. Mossoul 1905.

Strasb[ourg]: cf. BNF.

Urmia: Oshana Saru, Catalogue of the Syriac manuscripts in the Library of the Museum Association of Oroomiah College (Qodiqos d-ktabe suryaya d-gau bebliytiqi d-Collijiya d-Urmi). Oroomiah, Persia, 1898.

Vat[ican]: S.E. Assemanus \& and J.S. Assemanus, Bibliothecae apostolicae vaticanae codicum manuscriptorum. Catalogus in tres partes distributus. Partis Primae, Tomus secundus, complectens codices chaldaicos sive syriacos. Rome 1758. Partis Primae, Tomus tertius complectens reliquos codices chaldaicos sive syriacos. Rome 1759.

Vat[ican]: Arn. Van Lantschoot, Inventaire des manuscrits Syriaques des fonds Vatican (460-631), Barberini Oriental et Neofiti. Studi e testi 243. Vatican City, 1965.

\section{Secondary Literature}

Assemani BO iii,1: Joseph Simonius Assemani, Bibliotheca Orientalis Clementino-Vaticana. Tomi tertii, pars prima: De scriptoribus Syris Nestorianus (iii, 1.2). Rome 1725/1728.

Babakhan 1900: J. Babakhan, "Deux lettres d'Élie XI, patriarche de Babylone, texte syriaque et traduction française," Revue de l'Orient Chrétien, V (1900): 481-91.

Badger 1852: George Percy Badger, The Nestorians and their Rituals: With the Narrative of a Mission to Mesopotamia and Coordistan in 1842-1844, and of a Late Visit to Those Countries in 1850, etc., 2 vols. London 1852.

Baumstark 1922: Anton Baumstark, Geschichte der syrischen Literatur. Bonn 1922. 
Beltrami 1933: Mons. Giuseppe Beltrami, La Chiesa Caldea nel secolo dell'Unione. Orientalia Christiana 29. Rome 1933.

Bello 1939: P. Stéphane Bello, La congrégation de S. Hormisdas et l'église chaldéenne dans la première moité du XIXe siècle. Rome 1939.

Brown 1982: Leslie Brown, The Indian Christians of St Thomas. An Account of the Ancient Syrian Church of Malabar. Cambridge 1982 [second, enlarged edition].

Chabot 1896: J.-B. Chabot, "Les origines du patriarcat chaldéen. Vie de Mar Youssef Ier, premier patriarche des Chaldéens (1681-1695), écrite par Abdoulahad, archevêque chaldéen d'Amid, et traduite de l'arabe sur l'autographe de l'auteur," Revue de l'Orient Chrétien, 1 (1896): 66-90.

Chronicle 1939: Chronicle of the Carmelites in Persia and the Papal Mission of the XVII ${ }^{\text {th }}$ and XVIII th centuries, A, 2 vols. London, 1939.

Coakley 1992: J.F. Coakley, The Church of the East and the Church of England, A History of The Archbishop of Canterbury's Assyrian Mission. Oxford, 1992.

Coakley 1996: J.F. Coakley, “The Church of the East since 1914,” Bulletin of the Jobn Rylands University Library (Manchester) 78 (1996): 179_ 98.

Coakley, "patriarchal list': J.F. Coakley, "The patriarchal list of the Church of the East," to appear in the Drijvers Festschrift.

Coakley, "Eliya of Alqosh': J.F. Coakley, unpublished article on the "History of the Patriarchs of the Aboona Family," by bishop Eliya of Alqosh.

Da Seggiano 1962: P. Ignazio Da Seggiano O.F.M. Cap., L’Opera dei Cappuccini per l'unione dei cristiani nel vicino oriente durante il secolo XVII. Orientalia Christiana Analecta 163. Rome, 1962.

Fiey 1965: Jean Maurice Fiey, O.P., Assyrie Chrétienne. Contribution à l'étude de l'histoire et de la géographie ecclésiastiques et monastiques du nord de l'Iraq, volume I and II. Recherches publiées sous la direction de l'Institut de lettres Orientales de Beyrouth 22, 34. Beirut, 1965.

Fiey 1977: Jean Maurice Fiey, Nisibe, Métropole syriaque orientale et ses suffragants des rigines a nos jours. CSCO 388, Subsidia 54. Louvain, 1977.

Fiey 1993: Jean Maurice Fiey, O.P., Pour un Oriens Christianus Novus. Répertoire des diocèses syriaques orientaux et occidentaux. Beiruter Texte und Studien 49. Beirut, 1993.

Fiey: Fiey 1993: 21-41.

Graf 1949, 1951: Georg Graf, Geschichte der christlichen arabischen Literatur, vol. 3 and 4: Die Schriftsteller von der Mitte des 15. bis zum ende des 19. Jahrbunderts. [Studi e Testi 146, 147. Città del Vaticano, 1949 (3), 1951 (4). 
Giamil 1902: Samuel Giamil, Genuinae Relationes inter Sedem Apostolicam et Assyriorum Orientalium seu Chaldaeorum Ecclesiam nunc majori ex parte primum editae historicisque adnotationibus illustratae. Rome 1902.

Habbi 1966: Joseph Habbi, "Signification de l'union chaldéenne de Mar Sulaqa avec Rome en 1553," L'Orient Syrien 11 (1966): 99-132, 199-230.

Kawerau 1955/6: Peter Kawerau, "Die nestorianischer Patriarchate in der neueren Zeit," Zeitschrift für Kirchengeschichte 67 (1955/6): 119-31.

Lampart 1966: Albert Lampart, Ein Märtyrer der Union mit Rom. Joseph I., 1681-1696, Patriarch der Chaldäer. Einsiedeln, 1966.

Lampart: Lampart 1966: 63-4.

Lemmens 1926a: P. Leonardus O.F.M. Lemmens, "Relationes nationem Chaldaeorum inter et Custodiam Terrae Sanctae (1551-1629)," Archivum Franciscanum Historicum XIX (1926): 17-28.

Lemmens 1926b: P. Leonardus O.F.M. Lemmens, "Notae criticae ad initia unionis Chaldaeorum (a. 1551-1629)," Antonianum I (1926): 205-18.

Mingana 1926: A. Mingana, D.D., "The Early Spread of Christianity in India," Bulletin of the John Rylands Library (Manchester), 10 (1926): 435-510.

Nau 1912: F. Nau, "Deux notices relatives au Malabar, et trois petits calendriers, d'après les manuscrits Bodl. Or. 667, et Paris Syr. 25,195 et suppl. Grec. 292,' Revue de L'Orient Chrétien, 2nd series VII/XVII (1912): 74-99.

Sanders 1978: J. Sanders, "Het klooster van Mar Awgen," Phoenix 24,1 (1978): 39-46.

Sanders 1997: J.C.J. Sanders, Assyro-chaldese christenen in oost-Turkije en Iran. Hun laatste vaderland opnieuw in kaart gebracht. Hernen 1997.

Tfinkdji: J. Tfinkdji, "L'Église chaldéene catholique autrefois et aujourd'hui," Annuaire Pontifical Catholique 1914 (1913): 449-525.

Tfinkdji: Tfinkdji 1914: 471-75.

Tisserant 1931: Eugène Tisserant, "L'Église nestorienne," Dictionnaire de Théologie Catholique XI,1 (1931): 158-323.

Tisserant: Tisserant 1931: 261-3.

De Vries, 1960: Wilhem de Vries, "Elias XIV., letzter netorianischer Patriarch von Alqos?”, Orientalia Christiana Periodica 26 (1960): 141-8.

Vosté 1930a: J.-M Vosté, O.P., "Les inscriptions de Rabban Hormizd et de N.-D. des Semences près d'Alqos (Iraq)," Le Muséon 43 (1930): 263-316.

Vosté 1930b: J.-M Vosté, O.P. , “Catholiques ou nestoriens?”, Angelicum 7 (1930): 515-23. 
Vosté 1931: J.-M Vosté, O.P., “Mar Iohannan Soulaqa. Premier patriarche des chaldéens, martyr de l'union avec Rome [†1555]," Angelicum 8 (1931): 187-234.

Vosté 1927: J.-M. Vosté, O.P., "Kas Kheder Maqdassi à Élie XII, patriarche nestorien d'Alqos," Orientalia 50 (1937): 353-65.

Wilmshurst 1998: David Wilmshurst, "The Ecclesiastical Organization of the Church of the East, 1318-1913,” D.Phil Thesis, Worcester College, Oxford, June 1998 [the work is submitted to CSCO for publication]. 